\title{
Urban Turf Fertilizer Rule for Home Lawn Fertilization'
}

\author{
Laurie E. Trenholm²
}

As of December 31, 2007, the Florida Department of Agriculture and Consumer Services (FDACS) adopted a rule that regulates products that can be used to fertilize home lawns. The Urban Turf Fertilizer Rule (RE-1.003(2) FAC) regulates what can be sold and marketed as an urban turf fertilizer and requires specific wording on the fertilizer bag. This rule was enacted in response to concerns over potential pollution of water resources resulting from the nitrogen $(\mathrm{N})$ and phosphorus $(\mathrm{P})$ in these fertilizers.

While a healthy lawn typically takes up and uses applied fertilizer for growth and protein production, nutrients may leach or run off into water bodies or groundwater when fertilizer is overapplied or applied to an unhealthy lawn. In an attempt to reduce this nonpoint source pollution, FDACS developed a rule to regulate the amount of $\mathrm{N}$ and $\mathrm{P}$ applied to lawns as fertilizer.

The rule requires that specific guidelines for $\mathrm{N}$ and $\mathrm{P}$ application rates be followed. Any fertilizer sold in bags weighing less than 50 pounds for use on home lawns has directions for use conforming to these requirements. The rates allowed follow University of Florida guidelines for maintenance of healthy lawns.

For $\mathrm{N}$ application, the amount that can be applied at any one time is determined by the percentage of the slowrelease $\mathrm{N}$ component. For example, if a fertilizer has $30 \%$ slow-release $\mathrm{N}$, a maximum of 0.7 pounds of $\mathrm{N}$ per 1,000 square feet of turf can be applied. If the fertilizer contains more than $30 \%$ slow-release $\mathrm{N}$, a maximum of 1 pound of $\mathrm{N}$ can be applied per 1,000 square feet of turf. It is currently not allowable to apply more than 1 pound of $\mathrm{N}$ per 1,000 square feet at any one time. For help in figuring out how much fertilizer this is, refer to ENH962, Figuring out Fertilizer for the Home Lawn at http://edis.ifas.ufl.edu/ ep221. Annual N application rates follow the UF/IFAS recommendations based on grass species and location in the state (Table 1 ).

For $\mathrm{P}$ application, a maximum of 0.25 pounds of $\mathrm{P}_{2} \mathrm{O}_{5}$ per 1,000 square feet is allowed per application, with no more than 0.50 pounds allowed annually. No additional $\mathrm{P}$ can be applied unless a soil test indicates that $\mathrm{P}$ levels are deficient.

The rule also requires that some specific language be prominently displayed on the fertilizer bags. The maximum area (in square feet) covered by the bag must be prominently displayed on the front of the bag. Additionally, the following precautionary statement must be on fertilizer bags: "Do not apply near water, storm drains, or drainage ditches. Do not apply if heavy rain is expected. Apply this product only to your lawn or garden, and sweep any product that lands on the driveway, sidewalk, or street back onto your lawn or garden."

The rule applies to different types of products, including mixed fertilizer, fertilizer-pesticide mixtures, manure-based fertilizers, and fertilizer-seed mixtures. An exception to the rule is for newly planted lawns. You may apply a starter fertilizer that contains higher $\mathrm{P}$ as a one-time application after planting to encourage establishment. Directions for

1. This document is ENH1089, one of a series of the Environmental Horticulture Department, Florida Cooperative Extension Service, Institute of Food and Agricultural Sciences, University of Florida. Original publication date January 2008. Revised March 2013. Visit the EDIS website at http://edis.ifas.ufl. edu.

2. Laurie E. Trenholm, associate professor, turfgrass specialist, Environmental Horticulture Department, Institute of Food and Agricultural Sciences, University of Florida, Gainesville, FL 32611. 
use of these fertilizers limit $\mathrm{P}$ application to no more than 1.0 pound of $\mathrm{P}_{2} \mathrm{O}_{5}$ per 1,000 square feet.

Commercial lawn care services that fertilize home lawns are regulated under state statute. Beginning in January 2014, these professionals will be required under Chapter 482.1562, Florida Statutes, to be certified in the Florida Green Industries Best Management Practices for Protection of Water Resources. They also must maintain a "Limited Certificate for Urban Landscape Commercial Fertilizer Application," similar to the pesticide applicator's license that professionals applying pesticides must maintain.

Maintaining a healthy lawn is your best defense towards reduction of nonpoint source pollution from fertilizers. To keep your lawn healthy, always follow the University of Florida recommendations at http://hort.ifas.ufl.edu/ yourfloridalawn/. Proper fertilizing, irrigation, and mowing practices will provide you with a Florida-Friendly lawn. 
Table 1. Current UF/IFAS recommendations for annual nitrogen fertilization rates based on species and location in state

\begin{tabular}{|c|c|}
\hline Species/Location $^{\mathrm{a}}$ & $\begin{array}{l}\text { Nitrogen Recommendations } \\
\left(\text { lbs } 1000 \mathrm{ft}^{-2} \mathrm{yr}^{-1}\right)^{\mathrm{b}, \mathrm{c}}\end{array}$ \\
\hline Bahiagrass - North & $2-3$ \\
\hline Bahiagrass - Central & $2-4$ \\
\hline Bahiagrass - South & $2-4$ \\
\hline Bermudagrass - North & $3-5$ \\
\hline Bermudagrass - Central & $4-6$ \\
\hline Bermudagrass - South & $5-7$ \\
\hline Centipedegrass - North & $1-2$ \\
\hline Centipedegrass - Central & $2-3$ \\
\hline Centipedegrass - South & $2-3$ \\
\hline St. Augustinegrass - North & $2-4$ \\
\hline St. Augustinegrass - Central & $2-5$ \\
\hline St. Augustinegrass - South & $4-6$ \\
\hline Zoysiagrass - North & $3-5$ \\
\hline Zoysiagrass - Central & $3-6$ \\
\hline Zoysiagrass - South & $4-6$ \\
\hline \multicolumn{2}{|c|}{$\begin{array}{l}\text { a North Florida is considered to be north of Ocala, Central Florida from Ocala to State Road 60, and South Florida the remainder of the state } \\
\text { south of State Road } 60 \text {. } \\
\text { bHomeowner preferences for lawn quality and maintenance level vary; therefore, we recommend a range of fertility rates for each grass } \\
\text { and location. Additionally, effects within a localized region (i.e., microenvironmental influences such as shade, drought, soil conditions, and } \\
\text { irrigation) necessitate that a range of fertility rates be used. 'These recommendations assume that grass clippings are recycled. }\end{array}$} \\
\hline
\end{tabular}

